\title{
Dar a ver: o olhar poético na obra de João Cabral de Melo Neto
}

\author{
Rafaela Cardeal ${ }^{1}$
}

\section{Introdução}

Um dos primeiros leitores críticos da poesia de João Cabral de Melo Neto foi Antonio Candido, com "Poesia ao Norte", artigo publicado no jornal Folha da Manhã em $1943 .{ }^{2}$ Candido reconhecia em Pedra do sono (1942), o livro de estreia do poeta pernambucano, uma tendência construtivista aliada às influências do cubismo e do surrealismo, destacando características como rigor, ordenação e plasticidade. Conclui-se, então, que há nesse "livrinho de moço" "qualidades fortes de poesia" - diz o crítico - "não sei de ninguém que tenha estreado com tantas promessas". Além de pressentir o futuro propício do poeta, ou até mesmo reconhecer a beleza de seus versos, a apreciação crítica não deixa de chamar a atenção do autor:

\footnotetext{
O erro de sua poesia é que, construindo o mundo fechado de que falei, ela tende a se bastar a si mesma. Ganha uma beleza meio geométrica e se isola, por isso mesmo, do sentido da comunicação que justifica neste momento a obra de arte. Poesia assim tão autonomamente construída se isola no seu hermetismo. Aparece como um cúmulo de individualismo, de personalismo narcisista que, no Sr. Cabral de Melo, tem um inegável encanto, uma vez que ele está na idade dessa espontaneidade na autocontemplação. O Sr. Cabral de Melo, porém, há-de aprender com os caminhos da vida e perceber que lhe será preciso o trabalho de olhar um pouco à roda de si, para levar a pureza da sua emoção a valor corrente entre os homens e, deste modo, justificar a sua qualidade de artista (CANDIDO, 200o, p. 18).
}

Esse conselho indica que o crítico aposta numa direção mais interessante que seguramente João Cabral poderia seguir em sua poesia. Recomenda-se o "trabalho de olhar um pouco à roda de si" como uma espécie de antídoto para combater a postura hermética, evitando, assim, a expressão demasiado individualista - ou, para usar as palavras de Candido, o "personalismo narcisista”. Com isso, seria possível chegar a uma poesia mais comunicativa, que partilhasse um "valor corrente entre os homens". A visualidade, que a

Doutoranda em ciências da literatura na Universidade do Minho, Portugal. E-mail: rafacardeal@gmail.com

2 Este artigo de Candido foi posteriormente reproduzido na revista Colóquio/Letras, de Lisboa, pela qual é aqui referenciada. 
princípio se manifesta como um relevo plástico e, mais tarde, será de fato uma obsessão cabralina, prefigura-se prontamente aos olhos do leitor na abertura do livro:

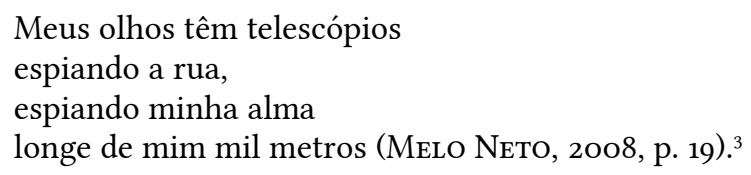

Os primeiros versos de "Poema", a composição inicial de Pedra do sono, parecem apontar para a natureza visual e metalinguística dessa poesia. Constrói-se, através uma perspectiva individual, o olhar de um sujeito que assume a posição de espectador do mundo. Seus olhos, intermediado por lentes que estendem sua capacidade de observação, espreitam tanto a realidade a "rua" - quanto o eu - a "alma" - de um ponto extraordinariamente afastado - "longe de mim mil metros". Verifica-se ainda que, ao buscar um distanciamento, um ponto de vista mais imparcial, o observador encontra-se isolado, não participando da dinâmica dessa realidade. De modo que o trabalho perceptivo conserva um rastro ensimesmado que chega a um clímax nos últimos versos do poema: "Ficarei indefinidamente contemplando / meu retrato eu morto" (p. 19).

Esse exemplo ilustra a constatação de Candido, uma vez que a visualidade, dentro de uma esfera onírica, estava relacionada ao individualismo e ao hermetismo. Mas esses aspectos serão gradativamente suprimidos nos livros posteriores, à medida que o poeta desenvolve um olhar voltado às coisas, à materialidade do mundo, em outras palavras, um trabalho de olhar ao que está ao redor de si. "Poesia ao Norte", ao desbravar a poesia de João Cabral, indicando as marcas fundadoras dessa poética, influenciou a produção do autor - foi responsável pela inclusão de Pedra do sono na obra reunida ${ }^{4}$ - e, principalmente, a recepção de seus versos, tornando-se o ponto inicial da

3 A partir de agora, as citações dos poemas de João Cabral de Melo Neto serão indicadas apenas pelo número da página referente à edição Poesia completa e prosa, organizada por Antonio Carlos Secchin.

4 Em 1985, João Cabral diz: "Eu poderia perfeitamente eliminar Pedra do sono [da minha obra]. Nele, a influência surrealista é muito forte, mas o Surrealismo só me interessou pelo trabalho de renovação da imagem. Antonio Candido, quando o livro foi lançado, escreveu um artigo admirável chamado 'Poesia ao Norte', dizendo que meus textos eram aparentemente surrealistas, mas com uma organização cubista. Por esse aspecto de construção é que decidi não renegar Pedra do sono" (ATHAYDE, 1998, p. 101). 
fortuna crítica cabralina. Se essa análise, por um lado, foi decisiva por ter consagrado o princípio construtivo ainda embrionário na altura; por outro lado, tornou canônica uma linhagem de interpretações que obedecem à cronologia de publicações de seus livros, produzindo uma estrutura linear, à maneira de um work in progress, que atinge o seu ponto mais alto com A educação pela pedra (1966).

Seguir a ordem cronológica de publicação dos livros de João Cabral nos dá uma noção de unidade que de fato existe na obra; entretanto, tal apreciação crítica poderia ser questionada, já que outras linhas de força mais descontínuas, igualmente presentes nessa poética, seriam de algum modo simplificadas. Apesar de se arriscar na cronologia como ordenação analítica, esta leitura pretende adotar um ponto de vista panorâmico acerca do olhar poético que será progressivamente desenvolvido pelo autor. Para compreender os muitos aspectos deste problema e os modos como se manifestam na construção da ótica cabralina, seria indispensável um exame mais detalhado, o que não será o intuito deste artigo. ${ }^{5}$ Dentro dos limites do que se propõe refletir aqui, é possível, porém, destacar ou inventariar certos momentos que demonstram a elaboração de um trabalho de ver, idealizado a partir de imagens poéticas de natureza perceptiva. Sem deixar de observar estratégias e procedimentos formais, destacaremos em cada livro os índices visuais que contribuirão para o prosseguimento da investigação. Em especial, no sentido de perceber como o poeta procura "responder" a crítica de Antonio Candido, já que, num primeiro momento, ele é aquele que vê e mais tarde torna-se aquele que dá a ver.

\section{O olhar cabralino}

Em Os três mal-amados (1943), a visualidade presente em Pedra do sono transforma-se em discurso poético na fala inicial de João - o primeiro dos mal-amados:

Olho Teresa. Vejo-a sentada aqui a meu lado, a poucos centímetros de mim. A poucos centímetros, muitos quilômetros. Por que essa impressão de que precisaria de quilômetros para medir a distância, o afastamento em que a vejo neste momento? (p. 35).

\footnotetext{
O presente artigo é uma versão modificada de um dos capítulos da dissertação de mestrado de minha autoria intitulada Visita ao Museu de tudo, de foão Cabral de Melo Neto (CARDEAL, 2016).
} 
A percepção distanciada de Teresa decorre da valorização de um campo lexical e metafórico ligado à visão, o que consequentemente provoca a subjetivação das imagens, submetidas ao ponto de vista do criador. Em uma leitura metalinguística, Teresa é a própria poesia, a representação da atmosfera onírica existente em uma concepção poética anterior, que será questionada: "Donde me veio a ideia de que Teresa participe de um universo privado, fechado em minha lembrança?” (p. 4o). É deste mundo hermético e individual, identificado por Antonio Candido em "Poesia ao Norte", que outro João o poeta João Cabral - também desejará se desvencilhar.

$\mathrm{Na}$ fala de Raimundo - o segundo mal-amado -, exibe-se um novo conceito poético a partir de Maria, caracterizada por uma sequência de imagens que personificam um mundo concreto: a praia, a fonte, o campo cimentado, a árvore, a garrafa de aguardente, o jornal, o livro, a folha em branco. É a partir dessa última imagem - a folha - que Raimundo construirá "um objeto sólido que depois imitarei, o qual depois me definirá" (p. 39). Essa renovada visão proporcionará a criação de "sistema estabelecido de antemão", no qual se elege a lucidez como "um modo novo e completo de ver uma flor, de ler um verso" (p. 40). A fabricação desse objeto artístico demonstra de algum modo um investimento técnico e artesanal que não anulará a expressão daquele sujeito, pois tal procedimento mimético, como num jogo de espelho, revelará as particularidades de seu criador.

Já em O engenheiro (1945), o embate entre a tendência onírica, representada pela fala de João, e a construtivista, delineada pelo discurso de Raimundo, não será totalmente resolvido. Nitidamente, o título do livro aponta para uma orientação racionalista que foi, sem qualquer dúvida, determinante para a elaboração e o desenvolvimento de todo um projeto estético e ético. Para além da definição de uma persona antilírica, o termo "engenheiro" - que se tornará, mais tarde, um dos epítetos mais populares de João Cabral - evidencia também o contato com as teorias do arquiteto suíço Le Corbusier, que, no contexto das décadas de 1910 e 1920, via na estética da engenharia a grande e verdadeira arquitetura. Uma de suas lições refere-se a uma concepção artística que privilegia a claridade, a lucidez e o construtivismo em detrimento do escuro, mórbido e espontâneo.

Le Corbusier foi responsável, segundo o próprio João Cabral, por "curá-lo" do surrealismo, tal "cura" implica uma doença: a atmosfera onírica e a valorização do inconsciente na atividade criativa e no ato de escrever. Mesmo 
livre desse mal, o "poeta engenheiro" conservará em sua dicção algo de surrealista, pois tal influência não provém da expressão poética, mas da pictórica, pois, diferentemente da palavra ditada pelo inconsciente, grande parte da pintura surrealista desenvolve-se por meio de princípios construtivos. De modo que certo gosto por imagens absurdas e por vezes ilógicas continuará presente na imagética cabralina. Com conquista de uma poesia solar, o ideal de claridade tornar-se-á uma forma de desvelamento de uma realidade "que nenhum véu encobre" (p. 46), delineada em $O$ engenheiro.

Como um "olho aberto sobre o mundo", 6 o sol será uma imagem fundamental que converterá a luz em uma transparência moral, criando, ao mesmo tempo, um valor plástico e ético. É no "castiço linho do meio-dia" (p. 65) - posição preferencial do sol cabralino - que se delineia a "Fábula de Anfion”, poema de Psicologia da composição (1947). Em linhas gerais, o poema ilustra o drama de Anfion ante Tebas, de um construtor que, ao se deparar com o acaso que faz soar sua flauta, acaba por edificar a cidade como num passe de mágica. Diante de sua obra, Anfion lamenta-se:

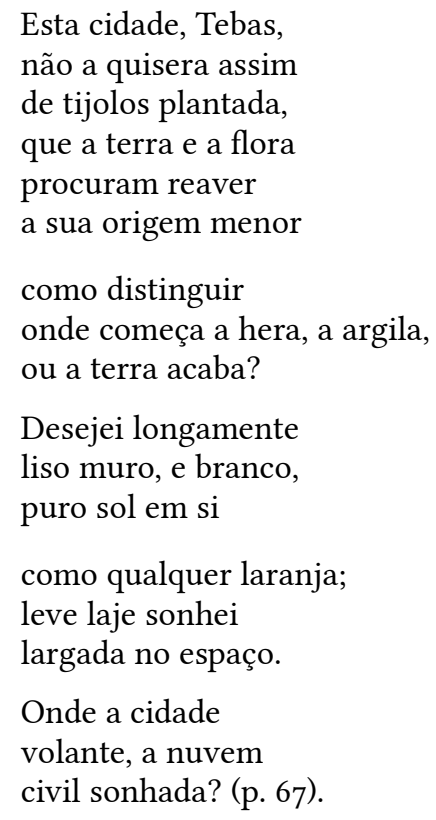

Anfion pretendia erguer uma cidade de justa sintaxe, feita a partir de um planejamento urbano, cujas referências apontam para o paradigma da

${ }^{6}$ Expressão de Gaston Bachelard (1986, p. 83). 
arquitetura moderna. À vista do irrealizável projeto de uma cidade "civil sonhada", Anfion volta-se contra o objeto criador: "Uma flauta: como / dominála, cavalo / solto, que é louco?” (p. 68) Admitindo a incapacidade de controlar o som ou as modulações de seu próprio instrumento, ele joga a flauta "aos peixes surdos-mudos do mar" (p. 68). Esse gesto de recusa ao acaso e à musicalidade poderá ser alegoricamente incorporado à obra, uma vez que o poeta, assim como Anfion, tentará construir um rigoroso horizonte, ${ }^{7}$ controlando o que há de irracional na criação poética.

Essa luta continuará a ser encenada em Psicologia da composição, poema que a partir das "lições" da "Fábula" pretende contornar, conceitualmente, o conflito anterior. Essa ligação é feita à medida que a imagem "cavalo solto e louco”, que caracteriza a flauta de Anfion, será reaproveitada na descrição do acaso: "O poema, com seus cavalos, / quer explodir / teu tempo claro; romper / seu branco fio, seu cimento / mudo e fresco" (p. 7o). Nesses versos, o "tempo claro" e o "cimento mudo e fresco", elementos que poderiam também qualificar a "cidade volante" que Anfion sonhara edificar, reaparecem ameaçados pelo descontrole animal. Os "cavalos" representam o que há de incontrolável no poema, mas que precisa ser dominado à força pelas mãos do criador, transformando-os em uma linguagem viva, porém contida, como "potros ou touros contidos" (p. 73).

Esse trabalho de rigor e justeza formal sinaliza uma abordagem racionalista que tem por base uma operação visual: "não a forma obtida / em lance santo ou raro, / tiro nas lebres de vidro / do invisível” (p. 71). A desconcertante metáfora de um "tiro nas lebres de vidro do invisível" aponta para o repúdio aos mecanismos arbitrários da criação poética, uma espécie de tiro sem mira, sem propósito ou objetivo. O controle sensível exercido na mira, num ponto determinado e visível, corresponde, portanto, à busca de uma precisão poética, ou ainda, de uma "forma atingida", a qual o tiro cabralino pretende sempre acertar. Nesse sentido, o abandono do invisível em favor das camadas visíveis do real reafirma o desejo de dar a ver, empreendido na obra de João Cabral.

Se o olho cabralino mira com precisão, esta não será alcançada somente com a representação estática. Em O cão sem plumas (1950) e O rio (1953) desenvolve-se uma dimensão cinematográfica: no primeiro, a narração visual volta-se para o objeto do olhar, o rio Capibaribe; no segundo, o próprio rio como personagem descreve o que vê no seu trajeto da nascente até a foz. Essa

\footnotetext{
“Riguroso horizonte”, verso de Jorge Guillén, é a epígrafe de Psicologia de composição.
} 
inversão de perspectiva nos parece indiciada em uma passagem de natureza biográfica d' $O$ rio:

\author{
Um velho cais roído \\ e uma fila de oitizeiros \\ há na curva mais lenta \\ do caminho pela Jaqueira, \\ onde (não mais está) \\ um menino bastante guenzo \\ de tarde olhava o rio \\ como se filme de cinema; \\ via-me, rio, passar \\ com meu variado \\ cortejo de coisas vivas, mortas, \\ coisas de lixo e de despejo (p. 113).
}

Ao descrever a região onde morava, o poeta vê-se como um "menino bastante guenzo" que antes olhava o Capibaribe como "filme de cinema" e agora, através da linguagem, reconstrói sua imagem, "onde [ele] (não mais está)". Esse processo de reconstrução de algumas paisagens da infância de João Cabral ocorre à medida que as memórias visuais são utilizadas como ponto de partida para o trabalho imagético. Além de associar o ato perceptivo à criação de imagens poéticas que se relacionam com a vivência do autor, a intensa descrição visual presente tanto em $O$ cão sem plumas quanto n'O rio compõe um retrato geográfico e humano, uma espécie de cartografia social, que culminará na perspectiva de Severino, em Morte e vida severina (1955), livro que compõe a trilogia do Capibaribe.

Em Paisagens com figuras (1955), a influência pictórica assinalada pelo título do livro indica a relevância representativa dos espaços que podem ser apreendidos pelo olhar, paisagens naturais, arquitetônicas e/ou poéticas, sem que se perca de vista o homem, as figuras que habitam esses cenários. Pernambuco e Espanha serão envolvidos por um horizonte comum, através do qual a semelhança física entre as paisagens nordestinas e espanholas evidenciará uma mesma existência severa ou severina. Nesse sentido, as dimensões estética, ética e humana estarão intimamente ligadas a uma educação fornecida pelo olhar, como é o caso de "Pregão turístico do Recife":

8 No poema autobiográfico "Prosas da Maré na Jaqueira", de A escola das facas, lê-se: "Maré do Capibaribe, minha leitura e cinema”. 
Do mar podeis extrair, do mar deste litoral, um fio de luz precisa, matemática ou metal. [...]

Com os sobrados podeis aprender lição madura: um certo equilíbrio leve, na escrita, da arquitetura.

E neste rio indigente [...] e na gente que se estagna nas mucosas deste rio, [...]

podeis aprender que o homem é sempre a melhor medida. Mais: que a medida do homem não é a morte mas a vida (p. 123).

Dos movimentos perceptivos em direção à cidade do Recife, é possível extrair alguns ensinamentos plásticos que recaem sobre uma conclusão de ordem existencialista, compondo quase um eco de Morte e vida severina. Esse embate entre a vida e a morte adquire um valor artístico, que se oferece como lição visual e poética, em "Alguns toureiros" (p. 133-134). O olhar atento à práxis desenvolvida por cinco toureiros apresenta-se nos versos que iniciam cada estrofe do poema: "Eu vi Manolo González" (v. 1); "Vi também Julio Aparício" (v. 5); "Vi Miguel Báez" (v. 9); "E (vi) também Antonio Ordóñez" (v. 13); "Mas eu vi Manuel Rodríguez" (v. 17). Mas é este último, o "mais agudo, / mais mineral e desperto", que se tornará um dos grandes mestres para a poesia de João Cabral:

\author{
sim, eu vi Manuel Rodríguez, \\ Manolete, o mais asceta, \\ não só cultivar sua flor \\ mas demonstrar aos poetas: \\ como domar a explosão \\ com mão serena e contida, \\ sem deixar que se derrame \\ a flor que traz escondida, \\ e como, então, trabalhá-la \\ com mão certa, pouca e extrema: \\ sem perfumar sua flor, \\ sem poetizar seu poema (p. 134).
}


As paisagens e as figuras espanholas, tão caras à poética cabralina, relacionam-se em "Estudos para uma bailadora andaluza", de Quaderna (1959). Nesse poema, o trabalho de construção imagética tem por objetivo simular o movimento dinâmico da dança flamenca, a fim de representar os vários aspectos da bailadora. À maneira de estudos pictóricos de um retrato, apresenta-se em cada uma das seis partes do poema uma metáfora diferente, assim, as imagens - fogo, cavalo-cavaleira, telegrafia, árvore, livro/estátua, espiga - serão hipóteses descritivas que revelam perspectivas diferentes acerca do objeto. Assim, cria-se a seguinte dinâmica: primeiro, elege-se uma imagem que funcionará como metáfora para a bailadora andaluza; depois, verifica-se a validade dessa imagem, confrontando-a com o objeto a ser representado; e, ao fim, recusa-se a imagem em prol de outra mais precisa. Esse mecanismo funciona como uma ética poética que se apoia numa "verdade de ver", através da qual se atinge, por assim dizer, uma representação mais fiel entre a realidade e a imagem. Surpreende, ao fim do poema, a escolha da última imagem, que como irrevogável talvez seja a mais expressiva:

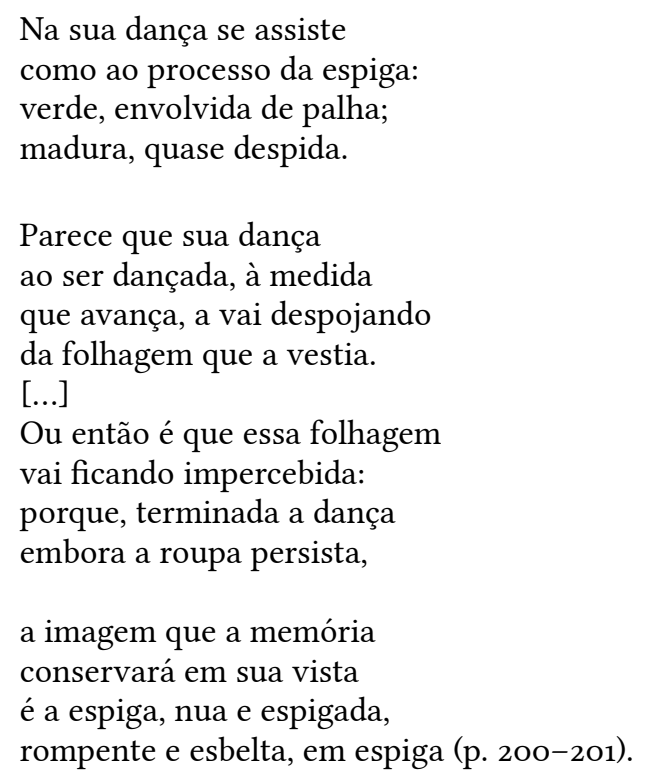

Essa espécie de "olho da memória", ou olhar mantido na vista da memória, demonstra-se em "De um avião" (p. 203-208), poema que descreve uma viagem "Pernambuco - Todos-os-Foras" a partir de "círculos" que vêm em uma espiral "da coisa à sua memória". Em cada "círculo", correspondente a um segmento do 
poema, constrói-se um novo cenário como consequência do afastamento espacial. O primeiro círculo, composto ainda no aeroporto, retrata a decolagem do avião; enquanto o segundo, já no ar, reconhece "na distância / de vidros lúcidos" algumas cidades pernambucanas, compondo na ótica daquele que vê uma paisagem familiar: que "por tê-la vestido por dentro, / mostra, a pequena altura, / coisas que ainda entendo". O terceiro círculo transforma a paisagem numa "folha de papel de seda / velando agora o texto":

\author{
Uma paisagem mais serena, \\ mais estruturada, se avista: \\ todas, de um avião, \\ são de mapa ou cubistas. \\ [...]

Se o afastamento visual progressivo pudesse causar certa depuração da experiência, ou uma hipotética perda do real, isso será evitado pela vigilância que o próprio poema se impõe, adotando uma postura crítica diante daquilo o que observa. Num primeiro movimento, a distância simplifica "com régua pura risca" as linhas da paisagem; num segundo, as linhas apagam-se, restando somente cores "o amarelo da cana verde, / o vermelho do ocre amarelo, / verde do mar azul, / roxo do chão vermelho". Mais uma vez, a distância que suprimiu por completo o traçado da paisagem reduz essas nuances a uma luz: "até que enfim todas as cores / das coisas que são Pernambuco / fundem-se todas nessa / luz de diamante puro".

O último círculo apresenta uma paisagem deformada que se tornou apenas uma lembrança, aquilo "o que coube à memória”, não podendo ser mais captada pelo olhar. Busca-se, ao fechar os olhos, encontrar um Pernambuco perdido, que se cristalizou na imagem do diamante, para desfazê-lo "de fora para dentro" para recompor "aquilo que, por primeiro, / se apagar, ficou mais oculto: / o homem, que é o núcleo / do núcleo de seu núcleo”. Mesmo com um intenso investimento na percepção de uma paisagem geográfica, que se 
converterá em uma paisagem poética, não se deixa de focalizar a figura, o humano e as suas questões como, no caso, a questão da memória afetiva do lugar em que se viveu.

O trabalho empreendido pelo olhar poético valida-se, em Serial (1961), como recurso cognitivo ao dialogar com a abstração geométrica de Piet Mondrian no poema "Escritos com o corpo", no qual os "escritos" - assim como os "estudos" da bailadora andaluza - buscam traduzir o corpo feminino através da corporeidade da escrita. Um dos meios de compreender esse "corpo frase" é a sistematização pictórica: "de longe como Mondrians / em reproduções de revista, / ela só mostra a indiferente / perfeição da geometria” (p. 271). Mas a frieza percebida, inicialmente, de uma perspectiva mais afastada, dará lugar a uma inesperada energia:

\author{
Porém de perto, o original \\ do que era antes correção fria, \\ sem que a câmara da distância \\ e suas lentes interfiram, \\ porém de perto, ao olho perto, \\ sem intermediárias retinas, \\ de perto, quando o olho é tato, \\ ao olho imediato em cima, \\ se descobre que existe nela \\ certa insuspeitada energia \\ que aparece nos Mondrians \\ se vistos na pintura viva (p. 271).
}

À pequena distância de um "olhar tato", confirma-se a simetria entre a expressão neoplástica do pintor holandês e a figura feminina. Entretanto, tal relação é logo desconstruída se se considerar o cromatismo dessa mulherpintura: ela "pode abrir mão da cor acesa" - "sem que um Mondrian não vibra" - e emocionar com a "textura em branco / da pele, ou da tela, sadia". Ainda dentro de uma abordagem plástica, que relaciona o processo compositivo pictórico ao poético, encontra-se "O sim contra o sim", poema que exibe, em seu último segmento, uma lição visual extraída de dois pintores. O primeiro "sim" é o de Juan Gris, pintor espanhol expoente do cubismo sintético, quem "levava uma luneta / por debaixo do olho" (p. 276). A luneta - instrumento óptico utilizado a priori para aproximar objetos distantes - é internalizada por 
Gris como técnica de composição de um ângulo de visão, à maneira de uma grande-angular, cujas lentes recuam como que "à altura de um avião que voava":

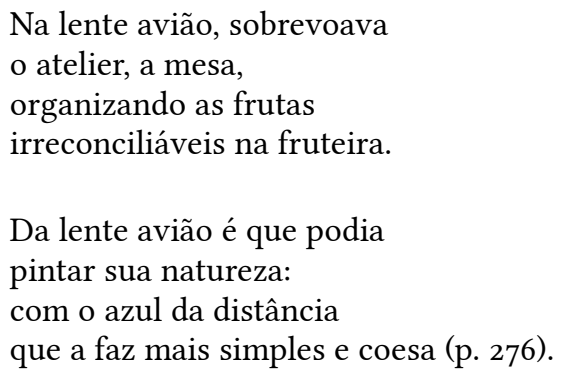

O segundo "sim" é representado por Jean Dubuffet, pintor francês idealizador da "arte bruta", que concebia o processo de criação como uma expressão primitiva e crua, rejeitando a ideia de uma estética visualmente agradável. Em oposição a Juan Gris, Dubuffet faz com a luneta "o que se faz com o microscópio", pois, em vez de querer aproximar o longe, ele procura ficar mais perto daquilo que já está perto:

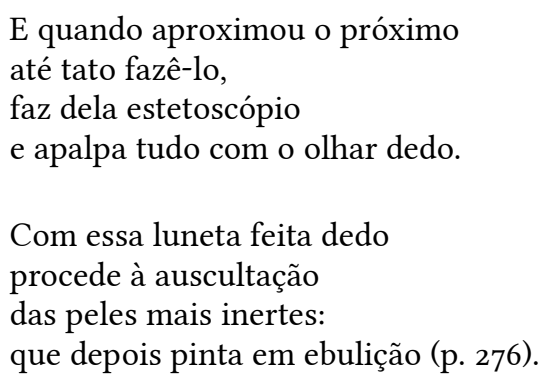

Nesse jogo "longe versus perto", o trabalho de olhar estará a serviço de processos criativos distintos que, em consequência, produzirão expressões artísticas contrativas: de um lado, a visão distanciada criará uma pintura "simples e coesa"; de outro, o contato tátil com as camadas táteis do real resulta em uma pintura "em ebulição". Essas duas formas de dar a ver, extraídas do olhar de Gris e de Dubuffet, poderiam conceituar na poética cabralina importantes técnicas visuais ou maneiras de ver: a "lente avião" e o "olhar dedo". Este último, um olhar que pretende tatear o real, parecer ser a tônica de "O ovo de galinha". Nesse poema, procura-se compreender a "arquitetura hermética" do ovo enquanto objeto, elaborando uma visão próxima à maneira cubista, mostrar todas as faces do que está sendo observado numa mesma 
perspectiva. Percebe-se, portanto, ao analisá-lo com um "olhar dedo", que se ao olho "se mostra / unânime a si mesmo, um ovo", à mão que o sopesa descobre nele "um peso que é vivo e não morto" (p. 278). No cruzamento dos dois sentidos, integrados a partir de um olhar fabricado no poema, dá-se a ver a "pura forma concluída" do ovo, sem ignorar sua condição existencial, pois apesar de ser uma espécie de produto final, ele "está no ponto de partida" da vida (p. 279).

Em A educação pela pedra (1966), a construção do olhar poético na obra de João Cabral conquista um maior grau de sofisticação plástica. Nesse livro, o investimento em uma "sintaxe visual" manifesta-se tanto na arquitetura do volume - que se estrutura em quatro partes, cada qual com 12 poemas quanto na rigorosa ordenação dos poemas - cada poema apresenta duas estrofes separadas ora por um asterisco, ora pelo número 2. Além disso, a primeira edição do livro contava com uma distribuição gráfica muito particular: um poema ocupava duas páginas, em outras palavras, as duas partes do texto apareciam lado a lado, uma em cada página, de modo que se podia observar, ao mesmo tempo, a dualidade estruturante de cada composição e a perspectiva do conjunto. Tal diagramação perdeu-se em todas as edições posteriores - com exceção da mais recente edição publicada em Portugal em $2006-,{ }^{9}$ segundo o autor, por uma conveniência econômica e de espaço exigida pelos editores.

Revela-se, ainda, a dualidade estruturante da obra nas relações formais estabelecidas entre os poemas, em especial entre os que se ligam por elementos comuns, evidenciados seja pelos títulos, seja no interior das composições. Nestas se estabelecem procedimentos inter-relacionais que criam jogos semânticos ou sintáticos entre pares, a partir do rearranjo parcial ou total dos versos, como é o caso de "Coisas de cabeceira, Recife" e "Coisas de cabeceira, Sevilha”. Apesar de apresentarem, em comparação aos outros pares, uma variação maior no que diz respeito aos versos, tais poemas aproximam-se de um gesto perceptivo:

\footnotetext{
9 A edição de $A$ educação pela pedra, publicada pela editora portuguesa Cotovia, recupera graficamente a disposição original da primeira edição.
} 
Diversas coisas se alinham na memória numa prateleira com o rótulo: Recife. Coisas como de cabeceira da memória. a um tempo coisas e no próprio índice; e pois que em índice: densas, recortadas, bem legíveis, em suas formas simples (p. 311).

Diversas coisas se alinham na memória Numa prateleira com o rótulo: Sevilha. Coisas, se na origem apenas expressões De ciganos dali; mas claras e concisas. A um ponto de se condensarem em coisas, Bem concretas, em suas formas nítidas (p. 318).

Nas primeiras estrofes de cada poema, a disposição visual de um espaço em que se pode expor ou arrumar objetos torna-se um ponto de partida para a organização de recordações imateriais. Tais itens são rememorados através daquilo que dão a ver: as formas simples - "densas, recortadas, bem legíveis" - da arquitetura de Recife; e as formas nítidas - "claras e concisas [...] bem concretas" - da linguagem de Sevilha. Nessa ordem, as primeiras coisas relacionam-se com a gramática visual da cidade e seus elementos arquitetônicos: o combogó, os paralelepípedos, telhados, sobrados. Já as segundas, com a gramática falada pelo povo daquela cidade e suas expressões idiomáticas: esparramarse, por derecho, com nervio, pies claros. Mesmo não sendo aparentemente visíveis, elas condensam-se em coisas de ver à medida que destacam posturas da dança flamenca. As qualidades de tais coisas que estão na "cabeceira da memória" de um e outro lugar são, em consequência, atributos poéticos da poesia de João Cabral.

Além da interação imagética entre alguns poemas de A educação pela pedra, há que se destacar um caso peculiar: em "Dois P.S. a um poema" produz-se um diálogo entre poemas de livros diferentes, no caso o volume referido e Quaderna. O poema retoma o processo metafórico de "Estudos para uma bailadora andaluza”, criando, assim, uma abordagem crítica da composição anterior. O post scriptum dedica-se a uma das imagens do poema matriz, a imagem do fogo - a primeira usada como metáfora para a dançarina flamenca -, verificando sua legitimidade comparativa. Apresenta-se ao leitor, nos primeiros versos de cada estrofe, um artifício metalinguístico: 


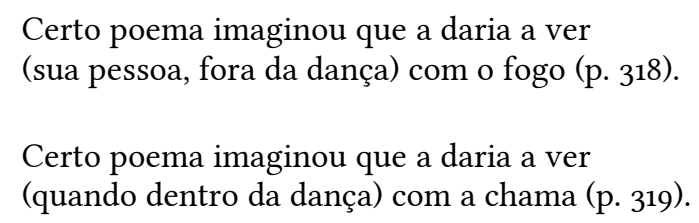

Em tais versos, após se instaurar a relação com "certo poema", evidencia-se que em cada estrofe demonstrará, em termos visuais, uma mulher a partir da relação de dentro e fora da dança. Na primeira estrofe do poema, aponta-se um "porém" acerca da equivalência que ela poderia ter com a imagem do fogo: ao contrário dele, que como "prisioneiro da fogueira" consome-se todo, ela tem o poder de se incendiar ou apagar quando quer. Já na segunda estrofe, a observação anterior estende sua autocrítica, uma vez que acrescenta outra ressalva ao poema, que se constitui como uma espécie da composição de Quaderna. "E embora o poema estime que a imagem / não conteria tudo", conclui-se também a ineficiência da imagem da chama, visto que esta só dança "da cintura para cima” (p. 319).

"Dois P.S. a um poema" é um caso interessante por criar uma espécie de construção em abismo, uma leitura crítica da leitura que um poema faz de uma realidade, e ainda por reforçar sintaticamente o dar a ver. Esse sintagma resume sinteticamente um dos principais objetivos teóricos que João Cabral procura com sua poesia. Mas como um conceito artístico, uma noção intelectual anterior à própria criação do poema, a expressão aparece de modo geral no discurso do poeta, em declarações e entrevistas, e raramente nos versos de um poema.

\section{A poética do dar a ver}

O dar a ver de João Cabral de Melo Neto tem origem no livro Donner à voir (1939), de Paul Éluard, que revelou ao poeta, nos seus anos de formação, a concepção visual e concreta de uma obra. Em 1986, o autor esclarece tal influência:

Éluard chamou de "Dar a Ver" um livro de poemas que ele fez sobre os pintores. Quando digo "dar a ver" é porque a minha poesia, em primeiro lugar, é mais visual do que musical. Em segundo lugar, digo "dar a ver" porque o poeta deve mostrar realidades sem tomar partido. Você mostra a realidade. Cada pessoa que veja como quiser (MORAEs, 2016, p. 15). 
Essa lição pictórica, extraída do poeta francês, também é reconhecida em outro criador: o brasileiro Murilo Mendes. A poesia de Murilo foi mestra na medida em que ensinou que "a palavra concreta, porque sensorial, é sempre mais poética do que a palavra abstrata" - disse João Cabral - "e que, assim, a função do poeta é dar a ver (a cheirar, a tocar, a provar, de certa forma ouvir: enfim, a sentir) o que ele quer dizer, isto é, dar a pensar" (ATHAyde, 1998, p. 137). A troca dos papéis entre quem exerce ou sofre o efeito de influência no poema "Texto de informação", publicado por Murilo Mendes em Convergência (1970):

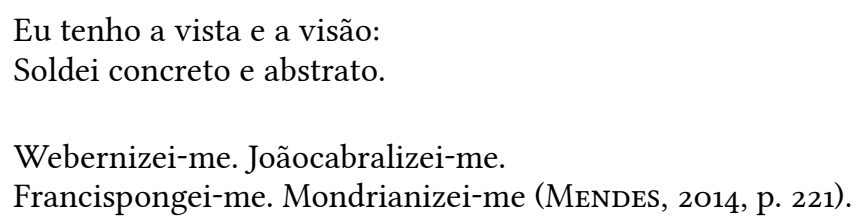

João Cabral influencia Murilo assim como Francis Ponge e Piet Mondrian, criadores também reverenciados pela obra cabralina. Ainda que partilhem uma fonte comum de "lições" artísticas, os dois brasileiros mostram soluções bem distintas em suas obras. Tais diferenças e afinidades serão demarcadas em "Murilograma a João Cabral de Melo Neto", poema que faz parte de uma extensa série dedicada a homenagear escritores e artistas, recriando a escritura alheia à maneira de Murilo Mendes. Na primeira parte da composição, alternam-se as aproximações entre as duas poéticas pelo uso da expressão "comigo e contigo" e as diferenças do emprego de "entre mim e ti". Deste modo, indicam-se os valores partilhados - "o Brasil", "a Espanha”, "Velázquez", "Graciliano" - e algumas particularidades que os separam - "a caatinga", "a montanha”, “o barroco", "Antonio Gaudí”, que se conciliam em um "fértil convívio \& ritmo alternado recíproco". Em seguida, na segunda parte do poema, confessa-se a profunda admiração pelo poeta pernambucano e o reconhecimento de sua obra singular:

Sim: não é fácil chamar-se João Cabral de Melo Neto. Força é ser engenheiro Mesmo sem curso \& diploma, Pernambucano espanhol Vendo a vida sem dissímulo; 


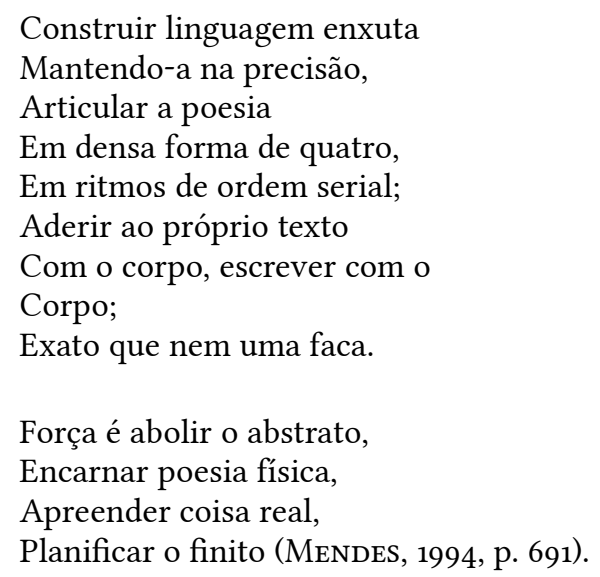

Na perspectiva de Murilo, ao construir uma linguagem enxuta e precisa, João Cabral procura "encarnar poesia física", que nunca cessará de "apreender coisa real". Indissociável do ato de ver, a escrita cabralina legitima-se, de acordo com Antonio Carlos Secchin (2014, p. 51), como uma "máquina de como ver o real", sentido extraído da epígrafe de $O$ engenheiro. A "máquina de comover", de Le Corbusier, um dos ideais cabralinos, converte-se então numa máquina de ver, num olhar poético que tem por finalidade produzir emoção no leitor. Tal plasticidade imagética, segundo o crítico, demonstra a construção de um artifício antilírico, assim, as "impregnações mais visíveis do sujeito" - afirma Secchin - camuflam-se "em prol de uma cena em que os objetos pareçam falar de si, mas sempre por meio do sotaque de quem os vê" (p. 401).

Desse modo, o conceito de dar a ver, ao contrário do que poderia parecer, apresentará implicações de ordem subjetiva. Em O que vemos, o que nos olha, Georges Didi-Huberman desenvolverá uma perspectiva filosófica acerca do dar a ver que se mostra útil para desconstruir a ideia de um olhar totalmente imparcial: o ensaísta francês dirá que "ver é sempre uma operação de sujeito" e, portanto, "todo olho traz consigo sua névoa, além das informações de que poderia num certo momento julgar-se detentor" (2010, p. 77). Denuncia-se, então, a impossibilidade de uma perspectiva neutra - ou, para usar as palavras do autor, de "um olho sem sujeito", por certo uma constatação quase óbvia, mas que desmonta a blindagem objetiva criada por João Cabral.

Convém lembrar que, para o autor, o dar a ver é um ato de pensamento, de modo que o olhar poético exposto em sua obra se distancia em muitos 
aspectos da percepção físico-óptica humana. Nesse sentido, o crítico literário Luiz Costa Lima (1995) argumenta que a ideia de visualização desempenhada na poética cabralina exerce uma função especial justamente por se afastar de uma expressão mimética, de uma realidade anterior ao texto. Esclarece-se que tal conceito não se apresenta como sinônimo de visão, pois esta é instrumento da percepção humana, enquanto a visualização é "um instrumento operativo, que implica relação dialética entre percepção e imaginação, entre recepção visual e sua transgressão formal” (p. 247). O lastro visual encontrado nos poemas, e consequentemente na obra, expressa-se, sobretudo, mediante a elaboração de uma técnica que permite criar uma linguagem poética orientada para ver.

\section{Poema é coisa de ver}

Nos últimos anos de vida, João Cabral de Melo Neto estava praticamente cego devido a uma doença degenerativa que o impossibilitou de manter suas atividades literárias. Esta observação de natureza biográfica será de grande utilidade para percebermos, a partir da perspectiva do autor, que a preponderância da visão em sua obra está em uma posição inicial do processo artístico, e não apenas de um resultado estético e/ou poético. Em entrevista ao jornal Folha de S. Paulo, realizada em 1994, o poeta pernambucano sinalizava um obstáculo:

Com esse negócio de olhos - estou com a visão muito ruim dos dois olhos -, acho muito difícil [voltar a escrever]. Eu, para escrever, preciso ver muito o que estou escrevendo, sou incapaz de compor uma coisa de cabeça e ditar. O poema, para mim, é como se eu pintasse um quadro. Preciso ver como é que está ficando a forma dele. De modo que tenho a impressão de que, apesar de ter muita coisa começada, não sei se eu poderei terminar (ATHAYDE, 1998, p. 83).

Ao contrário de outros poetas que passaram pela situação de privação visual, ou até mesmo pela completa perda de visão, e que, no entanto, tentaram contornar essa questão adaptando o seu processo de escrita, Cabral considerava-se incapaz de uma prática compositiva oral. Mesmo assim, contradizendo o próprio discurso, acima citado, ele teria "ditado" à Marly de Oliveira - sua companheira - um texto que é considerado o seu último "escrito": 


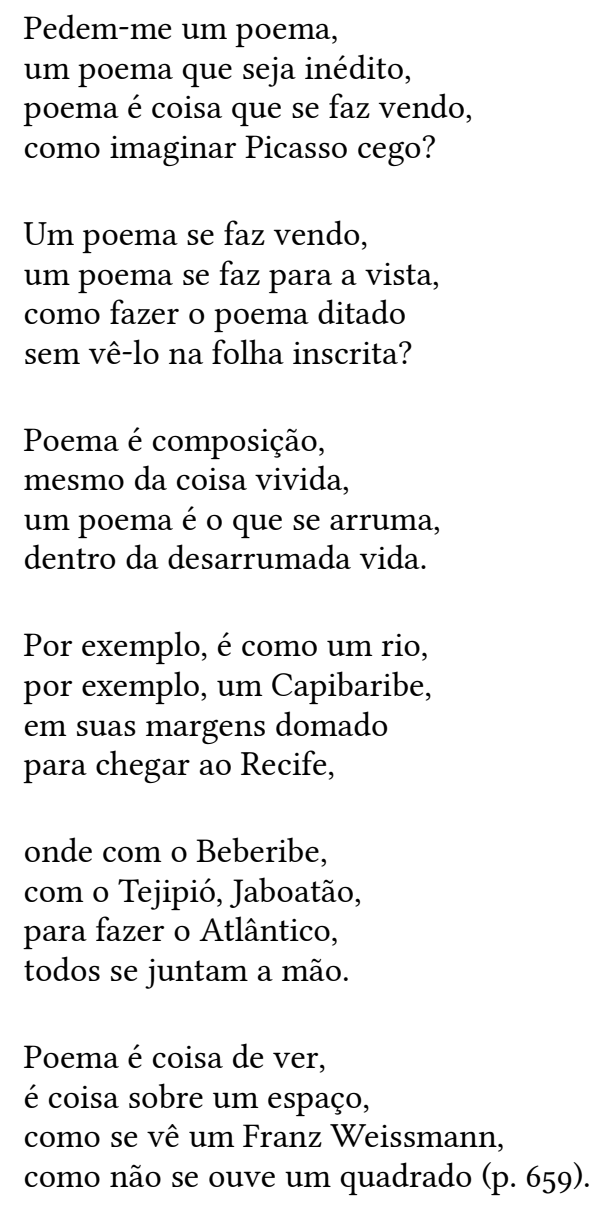

"Pedem-me um poema" nasce de um contexto biográfico: o crítico português Arnaldo Saraiva, em uma passagem pelo Rio de Janeiro em 1995, pediu a João Cabral um inédito para seu novo projeto, a revista Terceira margem. Alguns meses depois, Saraiva recebe de Marly a "encomenda", que aparecerá publicado no primeiro volume da revista, em 1998, um ano antes da morte do poeta. Independentemente de tal circunstância, o poema fundamenta uma concepção artística, de quem defende a poesia não como coisa dita ou audível, mas como “coisa de ver". Sem perder a estrutura visual característica da poesia cabralina - a organização estrófica em quadras -, impõe-se um questionamento fundamental: "como fazer o poema ditado / sem vê-lo na folha inscrita?".

Imaginar a cegueira de Picasso é uma possibilidade absurda, assim como o ato de criar em voz alta com o objetivo de que outro alguém transcreva, passando a escuta para a escrita, torna-se um projeto irrealizável para um 
poeta que escreve como se pintasse. João Cabral, ao relacionar sua privação visual com a suposta cegueira de um pintor, reafirma o primado da vista e do visto para a criação de sua poesia. A impossibilidade de observar o poema ganhar forma no papel, tal qual vê uma escultura de Franz Weissmann, assemelha-se à insuficiência de perceber por meio da audição a forma de um quadrado, uma abstração geométrica. Em síntese, o poema em questão, apesar de não ter sido publicado em livro, poderia ser um desfecho para a obra, uma vez que a perspectiva de que o "poema se faz para a vista” está amplamente exposta na obra do autor.

\section{Conclusão}

Na relação dialética entre percepção e imaginação, cria-se uma maneira de ver através do entrelaçamento de ver e do pensamento de ver, revelando, ao mesmo tempo, uma experiência perceptiva e uma reflexão crítica. Esse ponto de vista, de transformar um dado visual em poético, parece ter sido delineado em Poesia e composição: "O trabalho artístico é, aqui, a origem do próprio poema. Não é o olho crítico posterior à obra. O poema é escrito pelo olho crítico, por um crítico que elabora as experiências que antes vivera, como poeta” (Melo Neto, 2008, p. 45). Com o subtítulo A inspiração e o trabalho de arte, o ensaio - originalmente, uma conferência pronunciada na Biblioteca de São Paulo, em 1952 - identifica dois caminhos para a produção artística, evidenciando a preferência do poeta pela via da objetividade. Fica bastante claro, nesse trecho, que o olhar cabralino pode ser visto como uma tentativa de superar a subjetividade, de autenticar o seu conhecido antilirismo.

Por isso, o olhar do poeta parece ser filtrado por lentes objetivas de modo que se pudéssemos considerar que esses olhos "têm telescópios" - assim como a voz em primeira pessoa de "Poema", de Pedra do sono -, estes funcionam de uma maneira muito particular: criam, à maneira de uma câmera, um zoom conforme a exigência representativa, produzindo ora o efeito de afastamento com a "lente avião", ora o de aproximação com o "olhar dedo". Mas, mesmo procurando "fazer poesia com coisas" (p. 350), o poeta apresenta-nos um questionamento sobre a referencialidade, pertinente à sua obra, ao imaginar as supostas "dúvidas apócrifas" de Marianne Moore, que assim como ele também evitou falar de si: "Mas na seleção dessas coisas / não haverá um falar de mim?" (p. 522). Essa suposta confissão em terceira pessoa, exibida tardiamente no livro Agrestes (1985), demonstra a consciência daquele que ao retratar as coisas através da 
escrita acaba por construir uma imagem refletida de si próprio. Em outras palavras, João Cabral de Melo Neto, aquele que dá a ver, dá-se a ver.

\section{Referências}

Athayde, Félix de. Ideias fixas de foão Cabral de Melo Neto. Rio de Janeiro: Nova Fronteira, 1998.

BACHelard, Gaston. O direito de sonhar. São Paulo: Difel, 1986.

CAndido, Antonio. Poesia ao Norte. In: CAndido, Antonio. Um velho artigo. Colóquio/Letras, Lisboa, n. 157/158, p. 13-19, 2000.

CARDEAl, Rafaela. Visita ao Museu de tudo, de foão Cabral de Melo Neto. Dissertação (Mestrado em Literatura Brasileira) - Universidade Federal do Rio de Janeiro, Rio de Janeiro, 2016.

Didi-Huberman, Georges. O que vemos, o que nos olha. São Paulo: Editora 34, 2010.

LimA, Luiz Costa. Lira e antilira: Mário, Drummond, Cabral. Rio de Janeiro: Topbooks, 1995.

Melo Neto, João Cabral de. Poesia e prosa completa. Organização de Antônio Carlos Secchin. Rio de Janeiro: Nova Aguilar, 2008.

Mendes, Murilo. Texto de informação. In: Mendes, Murilo. Antologia poética. São Paulo: Cosac Naify, 2014.

Mendes, Murilo. Murilograma a João Cabral de Melo Neto. In: Mendes, Murilo. Poesia completa e prosa. Rio de Janeiro: Nova Aguilar, 1994.

MorAes, Geneton. João Cabral de Melo Neto: uma aula do poeta que combatia a "emoção fácil" na poesia. Genetom.com.br, [S.1.], 10 jun. 2007. On-line. Disponível em: <http://www.geneton.com.br/archives/000 210.html>. Acesso em: 15 jan. 2016.

SARAIVA, Arnaldo. Dar a ver e a se ver no extremo: o poeta e a poesia de João Cabral de Melo Neto. Porto: Afrontamento, 2014.

Secchin, Antonio Carlos. João Cabral: uma fala só lâmina. São Paulo: Cosac Naify, 2014.

Recebido em 22 de fevereiro de 2017.

Aprovado em 28 de maio de 2017.

\section{Resumo/Abstract/Resumen}

\section{Dar a ver: o olhar poético na obra de João Cabral de Melo Neto \\ Rafaela Cardeal}

Este artigo propõe uma reflexão sobre a questão da visualidade desenvolvida na obra de João Cabral de Melo Neto, a partir do conceito de "dar a ver", um de seus principais objetivos poéticos. Com uma leitura abrangente que acompanhará o percurso desde Pedra do sono (1942) até A educação pela pedra (1966) - o livro de estreia e o exemplar que marca o ápice da trajetória do autor, respectivamente - analisaremos algumas imagens e 
propriedades resultantes da percepção visual. Veremos de que maneira a escrita cabralina, apesar de procurar uma perspectiva objetiva, denuncia a mirada do poeta.

Palavras-chave: João Cabral de Melo Neto, dar a ver, olhar poético, literatura brasileira.

\section{Give to see: the poetic sight in the work of João Cabral de Melo Neto}

Rafaela Cardeal

This paper proposes a reflection on the issue of sight, having as theoretical support the concept of "to give to see", conceived by João Cabral de Melo Neto in his work. With a critical reading that will specifically examine the development of Melo Neto's poetry from Pedra do sono (1942) to A educação pela pedra (1966) - the first book and the one that represents the high point of the author's poetics, respectively -, we will investigate some images and proprieties resultant of the visual perception. Melo Neto's writing seems to expose the target of his look despite seeking an objective perspective.

Keywords: João Cabral de Melo Neto, give to see, poetic sight, Brazilian poetry.

\section{Dar a ver: la mirada poética en la obra de João Cabral de Melo Neto}

\section{Rafaela Cardeal}

Este artículo propone una reflexión sobre la cuestión de la visualidad desarrollada en la obra de João Cabral de Melo Neto, a partir del concepto de "dar a ver", uno de sus principales objetivos poéticos. Con una lectura completa que acompañará el recorrido desde Pedra do sono (1942) hasta A educação pela pedra (1966) - el libro de estreno y el ejemplar que marca el ápice de la trayectoria del autor, respectivamente - analizaremos algunas imágenes y propiedades resultantes de la percepción visual. Veremos de qué manera la escritura de Melo Neto, a pesar de buscar una perspectiva objetiva, denuncia la mirada del poeta.

Palabras clave: João Cabral de Melo Neto, dar a ver, mirada poética, literatura brasileña. 